Primljen / Received: 29.10.2015. Ispravljen / Corrected: 20.9.2017.

Prihvaćen / Accepted: 2.7.2018. Dostupno online / Available online: 10.10.2018.

\section{Physical model study for evaluation of jet impact on sediment flushing}

Professional paper

Ahmad Abdipour, Hassan Ahmadi, Seyed Abbas Hosseini

Physical model study for evaluation of jet impact on sediment flushing

Pressure flushing is one of the methods that are used for removing sediments from reservoirs. In this research, submerged jets were used in front of the dam. A physical model was developed to study the influence of jet characteristics (nozzle diameter, jet velocity, and jet discharge) and reservoir output parameters (bottom outlet level and discharge) on the sediment release. The efficiency of the jets was established by comparing the sediment scour obtained under different conditions: once with jets and once without jets. The sediment scouring efficiency ranged between 0.9 and 3.1 for jet experiments, and between 0.1 and 0.3 for reference tests (without jets).

Key words:

pressure flushing, physical model, sediment scouring, jet velocity, nozzle diameter

Stručni rad

Ahmad Abdipour, Hassan Ahmadi, Seyed Abbas Hosseini

\section{Analiza fizikalnog modela za ocjenu utjecaja mlaza na ispiranje nanosa}

Ispiranje pod tlakom jedna je od metoda koje se primjenjuju za uklanjanje nanosa iz akumulacija. U ovom se istraživanju koriste uronjeni mlazovi u zoni ispred brane. Na fizikalnom modelu istražen je utjecaj karakteristika mlaza (promjer mlaznice, brzina mlaza i protok) i izlaznih parametara akumulacije (razina i protok temeljnog ispusta) na ispiranje sedimenta. Učinkovitost mlazova određena je uspoređivanjem ispiranja nanosa pod raznim uvjetima: jednom uz korištenje mlazova i jednom bez njih. Učinkovitost ispiranja nanosa varirala je od 0,9 do 3,1 kod ispitivanja s mlazom, te između 0,1 i 0,3 za kontrolna ispitivanja (bez mlaza).

Ključne riječi:

ispiranje pod tlakom, fizikalni model, uklanjanje nanosa, brzina mlaza, promjer mlaznice

Fachbericht

Ahmad Abdipour, Hassan Ahmadi, Seyed Abbas Hossein

Physikalische Modellanalyse für die Bewertung des Einflusses des Strahls auf die Auswaschung von Ablagerungen

Das Auswaschen unter Druck ist eine Methode, die bei der Beseitigung von Ablagerungen aus der Akkumulation angewendet wird. In dieser Untersuchung werden eingetauchte Strahlen in der Zone vor dem Damm verwendet. Am physikalischen Modell wurden der Einfluss der Strahleigenschaften (Durchmesser des Strahls, Geschwindigkeit des Strahls und Durchfluss) sowie die Ausgangsparameter der Akkumulation (Niveau und Durchfluss des grundlegenden Auslasses) auf die Auswaschung des Sediments untersucht. Die Wirksamkeit der Strahlen wurde durch Vergleich der Auswaschung der Ablagerung unter verschiedenen Bedingungen festgelegt: einmal durch Anwendung von Strahlen und einmal ohne diese. Die Wirksamkeit der Auswaschung der Ablagerungen variierte von 0,9 bis 3,1 bei der Untersuchung mit dem Strahl und zwischen 0,1 und 0,3 bei der Kontrolluntersuchung (ohne Strahl).

Schlüsselwörter:

Auswaschung unter Druck, physikalisches Modell, Beseitigung von Ablagerungen, Strahlgeschwindigkeit Strahldurchmesser 


\section{Introduction}

On an average, the capacity of dams reduces by $3 \%$ annually, which is caused by sedimentation (corresponding to 45 million $\mathrm{m}^{3}$ per year) [1]. Several methods have been proposed to control the sedimentation process, including watershed management, flushing, hydro-suction, sluicing, turbidity current venting, and dredging. The use of these methods requires full understanding of their capabilities and limitations. Sometimes, they may even not be economically justified in some reservoirs $[2,3]$. In hydraulic sediment scouring, the height of the water in the reservoir is always higher than the bottom outlet gates; thus, the sediments that aggregate at the back of the dam would be removed by sudden opening of the bottom outlet gates of the dam. In this method, after some time of sediment scouring, a funnel-shaped scour cone is created at the front bottom outlet. In a pressurized hydraulic sediment scour, the depth of water in the reservoir must be lowered as much as possible, and the time of implementation should be selected in such a way that first, the level of water should be close to utilization of the minimum level, and second, the bottom outlets should be completely open so that their entire cross section can be used.

As a result of the aforementioned, many studies have been dedicated to the investigation of the jet phenomenon and scouring, including Rajaratnam and Mazurek [4], Sequeiros and Garcia [5], and Ghodsian and Salehi [6]. The outlet flow from the hydraulic structures acting like a jet and causing a scour cone in their downstream beds is addressed in their experiments. Some examples are the scour downstream of the vertical gates, flip bucket spillways, weirs, drops, and culverts. The jet is a concentrated flow, where the higher velocity fluid of the jet discharges into an ambient fluid that is either at rest or in motion. The jet can be either unsubmerged, like the case of a water jet discharging into the air, or it can be submerged, where the jet is discharging into the same fluid. The most important hydrodynamic forces acting on sediment particles are the jet momentum, drag force or drift, and resistive forces such as the shear force. The main principle in the use of a submerged water jet to flush sediment is that the jet generated by boundary shear stress is greater than that of the shear strength of the cohesive sediment. Thus, the momentum exchange is caused by the
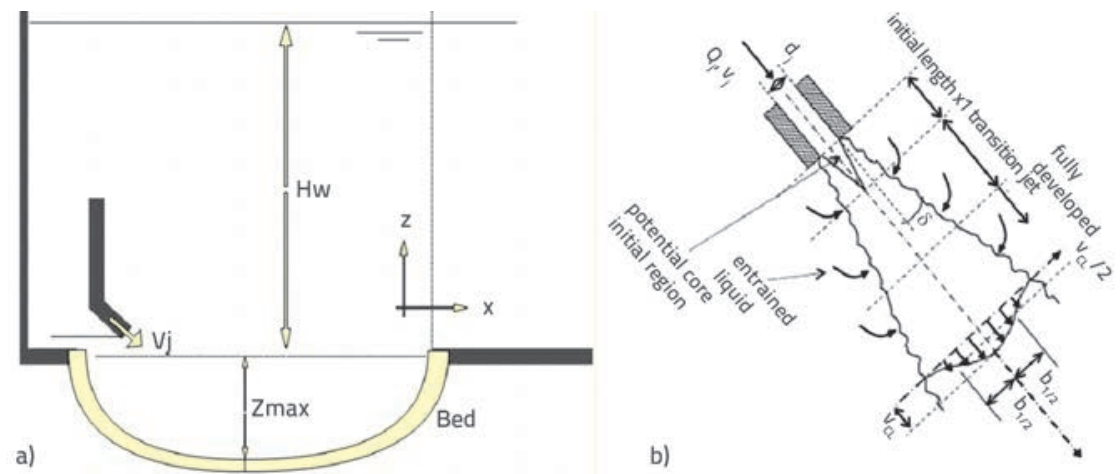

Figure 1. a) Scour cone induced by submerged jet; b) Jet flow behaviour according to Blevins theory sediment and the surrounding environment. When the sediment and jet are at the same speed, the sediments gradually spread to the surrounding environment with the jet and form the hole. Extensive research has been performed in the field of jet mixing. The following parameters and their influence on mixing time have been reported: jet velocity [7], jet diameter [8], jet angle and jet length [9], and multiple jets [10]. Figure 1 shows the behaviour of a jet flow according to Blevins theory [11]. As shown, jet flow includes three regions: initial region, transition region, and a fully developed region. The initial region is composed of a core central flow and a shear layer surrounding it. The velocity in the centric section is equal to the outlet velocity of the jet nozzle $\left(V_{j}\right)$ for a uniform outlet velocity. The central core flow is almost shear-free and is often called the potential flow or potential core. This central core flow is surrounded by a turbulent shear layer called the mixed layer. This layer forms a boundary between the central core flow and reservoir fluid. In the transition region, the fluid starts to add to the jet flow and in the fully developed region, this mixing is completed and the mixed layer penetrates into jet axis. The velocity of jet flow in the central line reduces by getting further from the outlet and reaching the developed region. Jenzer et al. [12] studied the jet flows by using rotational flows caused by circular jets discharging the inlet muddy flows from power intake (Figure 2).
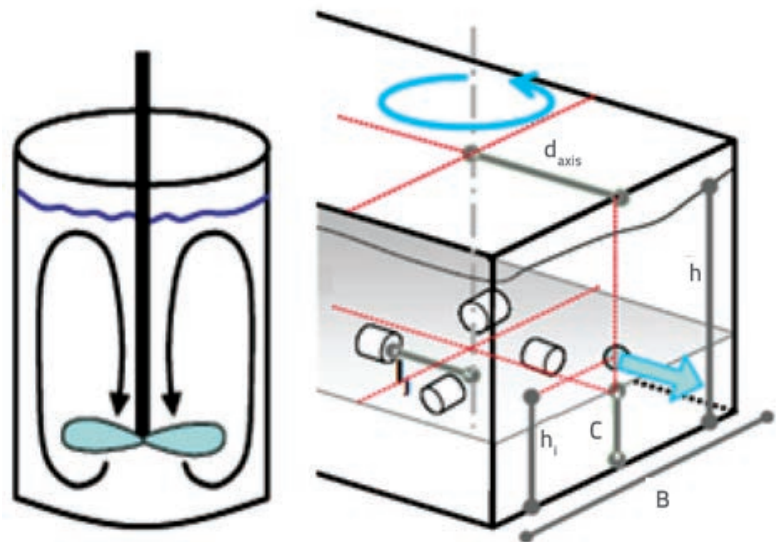

Figure 2. Rotational jets experimental model made by Jenzer et al. [12]

They concluded that jets increase the release efficiency between 1.5 and 2 times as compared to the reference case without jets. The upward or horizontal jets were used in their study.

In this research, the downward submerged jets are used for the first time in order to increase sediment scour and its removal from the reservoir. The jet method does not require a complicated system and is completely practical. Moreover, this method is economical as it decreases the costs 
caused by sedimentation threat near a hydropower dam, danger of sediment entrance into the power intake tunnels, and damage to turbines and equipment; besides, it increases the reservoir capacity. This method is suitable for dams that are already under operation and the sediment has already built up to some extent. However, this method can be applied for new uses with some modifications and, in this way, jets can prevent sedimentation and its level will increase. The result of this study is obtained in experimental conditions.

\section{Experimental setup}

The experimental model measures $2.3 \mathrm{~m}$ in length, $1.2 \mathrm{~m}$ in width, and $1.2 \mathrm{~m}$ in depth. According to Figures 3 and 4, the model consists of three main parts: input area (or flow dissipater area), main reservoir, and settling basin area. The grading characteristics of the reservoir bed material were $d_{50}$ $=0.22 \mathrm{~mm}, \mathrm{~d}_{84}=0.28 \mathrm{~mm}, \mathrm{~d}_{16}=0.17 \mathrm{~mm}$ and $\sigma=\left(\mathrm{d}_{84} / \mathrm{d}_{16}\right)^{0,5}$ $=1.28$, where $d_{x}$ is the characteristic diameter for which $x \%$ of the material is finer. The experiments were performed for two different cases: jet and reference (without jet) experiments. Water was supplied by a pump at a desired steady flow by controlling the valve of the pipe. The outlet can be inserted at two different levels: $\mathrm{H}_{1}=0.15 \mathrm{~m}$ and $\mathrm{H}_{2}=0.30 \mathrm{~m}$ above the bottom with a diameter of $5.08 \mathrm{~cm}$ placed in the middle of the front wall. Flow rates $\mathrm{Q}_{\text {out }}$ through the outlet varied from 1 to $4 \mathrm{~L} / \mathrm{s}$. They are controlled by a valve and monitored with a V-notched weir plate at the basin outlet. Water with a discharge $Q_{j}$ was equally subdivided into five jets and was measured using a rotameter. Experimental tests were conducted by varying the total discharge $\mathrm{Q}_{\mathrm{j}}$ between $0.2 \mathrm{~L} / \mathrm{s}$ and $2.2 \mathrm{~L} / \mathrm{s}$. The nozzles were fixed at the lower end of the rigid pipes at $\alpha=45^{\circ}$, where $\alpha$ is the inclination angle of the jets with respect to the horizontal plane. The nozzle position and its diameter $d_{i}$ can be varied $(4,6$ and $8 \mathrm{~mm})$. At the beginning of the experiment when the downstream outlet was opened, sediments were discharged with high concentration, though the concentration decreased with time. The experiments continued until the scouring cone reached equilibrium, such that the sediment concentration was negligible at the end of the experiments. The condition of the experiments is shown in Table 1.

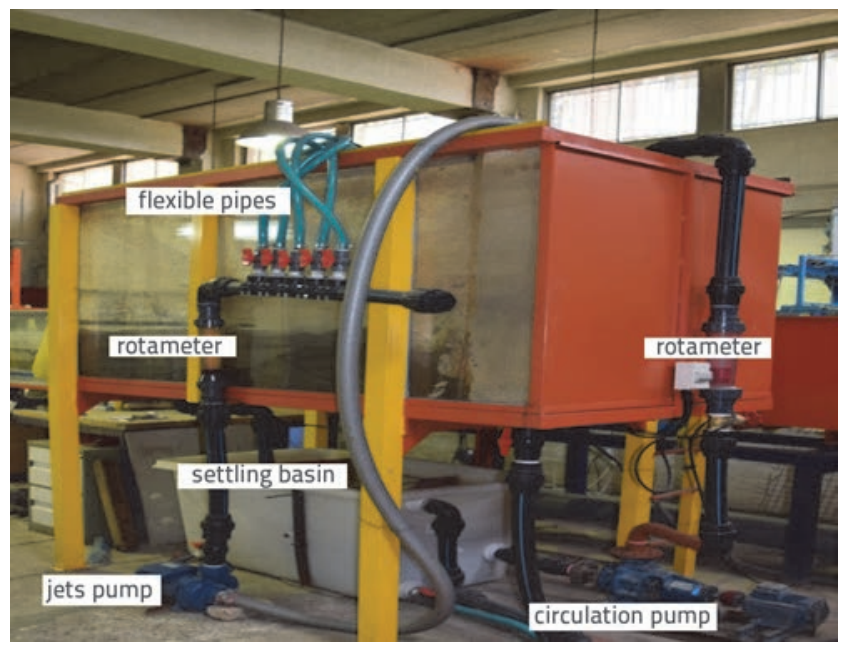

Figure 3. Picture of the tank with the two rotameters and flexible and rigid pipes leading the water down to the nozzles

All through the experiment, the trial was stopped at different time intervals and the volume of the removed sediments was measured. The scour hole dimensions were measured in static conditions. In static measurements, the pumps were turned off and, after the tank drainage, the scour profiles were measured. After each experiment, the sediment scouring profile was obtained using a LASER meter installed on a carrier. The parameters influencing effectiveness of the jets are the jet velocity, jet diameter, and geometry of their arrangement. Before the main experiments, some initial tests were conducted to achieve an optimized arrangement of jets. At first, only one jet was used and its effectiveness zone was determined based on height of water in the reservoir. The resulting pressure on nozzles
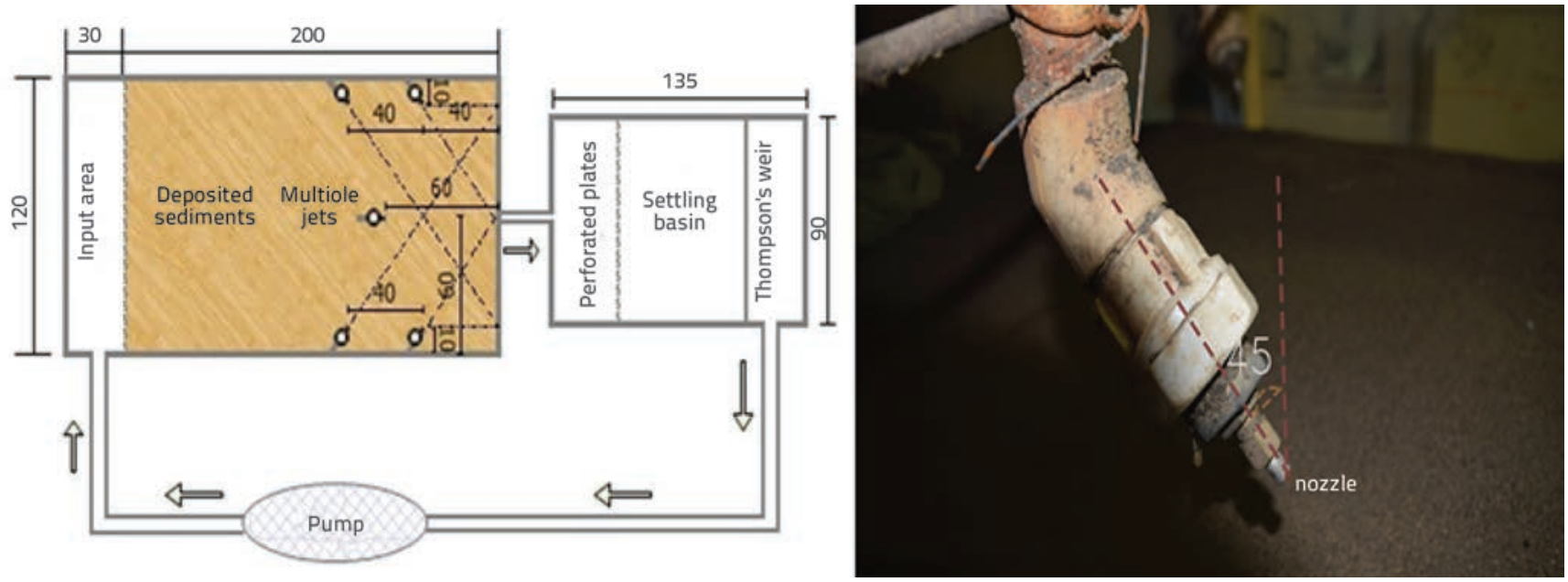

Figure 4. Schema of the experimental installation (left) and jets configuration (right) 
Table 1. Experimental conditions for reference and jet tests

\begin{tabular}{|c|c|c|c|c|c|c|c|c|}
\hline Experiment & $\mathrm{H}_{\mathrm{s}}[\mathrm{cm}]$ & $\mathbf{H}_{w}[\mathrm{~cm}]$ & $\mathbf{H}_{\text {out }}[\mathrm{cm}]$ & $\mathbf{Q}_{\text {out }}[\mathrm{lit} / \mathrm{s}]$ & jet.N & $\mathbf{d}_{\mathrm{j}}[\mathrm{mm}]$ & $\sum \mathbf{Q}_{\mathrm{j}}[\mathrm{lit} / \mathrm{s}]$ & $\begin{array}{l}\text { Number of } \\
\text { experiments }\end{array}$ \\
\hline With jet & 30 & $40,70,100$ & 15 & $1-4$ & - & - & - & 15 \\
\hline Without jet & 30 & 100 & 15,30 & $1-4$ & 5 & $4,6,8$ & $0,2-2,2$ & 30 \\
\hline \multicolumn{8}{|c|}{ Total number of experiments } & 45 \\
\hline
\end{tabular}
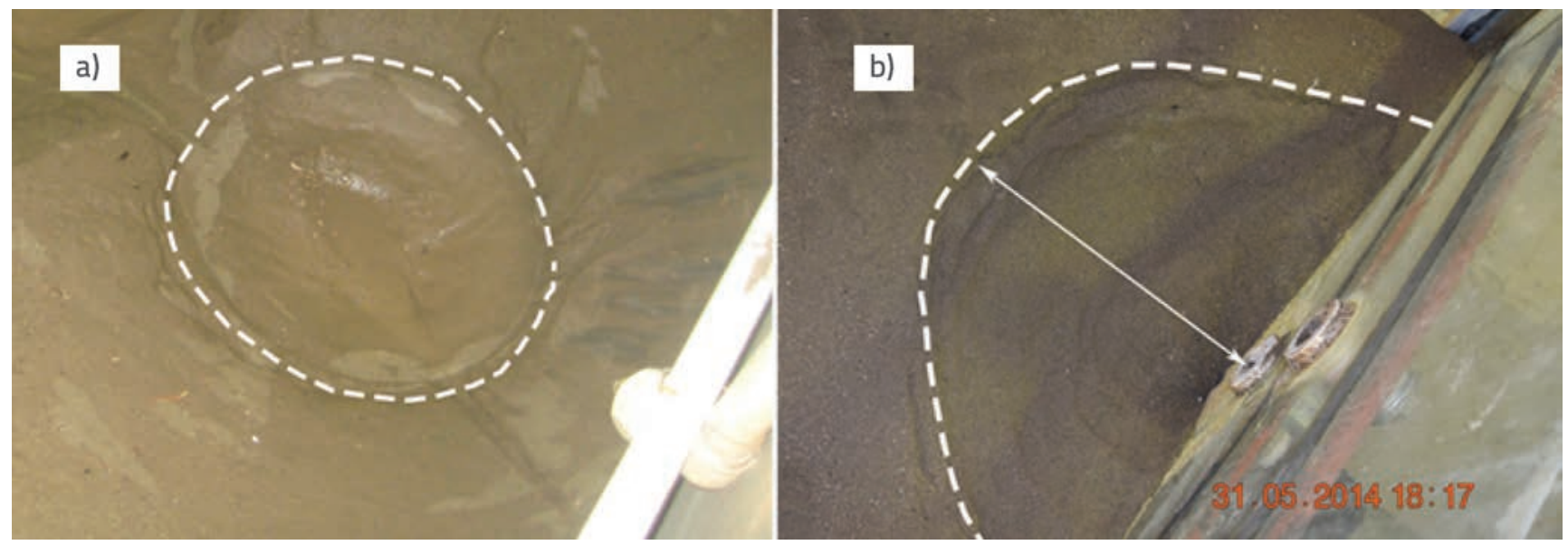

Figure 5. View of the scour hole: a) jet experiment; b) reference (without jet) experiment

was also determined for different velocities and diameters (Figure 5.a). Moreover, the effective zone of the bottom outlet at different discharges was determined based on the reference (without jet) experiments (Figure 5.b). The lateral jets push the sediments into the middle part of the reservoir and the accumulated sediments are guided to the effective zone of the outlet by the intermediate jet, and are then extracted by outlet suction. In this arrangement, besides scouring and removing the sediments, the jets conduct them in the forward direction. That is why the skewed form and downward inclination were selected. In vertical jets, the sediments are flushed in depth, but they are not guided into the outlet, while in the horizontal state, the jets do not hit the sediments. Therefore, due to dimensions of the existing tank, the jets were arranged in a way that guarantees their optimum performance. In this experiment, the ratio of the tank length over the width and the sediment grain size and densities are constant, and their effect on the sediment scour was not investigated. But when varying properties of sediments, the discharge range used in this study will not have the same effect on the sediment scour. Since cohesionless particles behave as individual particles, the erosion of sand will differ from that of clay. The resistance of sand to erosion results from its buoyant weight, such that the size and density of the particle and gravity must be considered in determining this resistance. In case of clay, electrochemical forces that bind the particles together control the clay resistance to erosion. Nevertheless, studies of the scour by jets in sand give an idea of what is to be expected in the scouring by jets in clays.

\section{Results and discussion}

To achieve the goals of this study, the variable parameters of flow were considered dimensionless. Free surface hydraulic models based on Froude similarity are usually performed. This means that the same relations are used for the inertia and gravity forces in the prototype. The ratio of the volume of removing sediment $\left(\mathrm{V}_{\mathrm{f}}\right)$ to the volume of water discharged $(V$ in the equilibrium time is defined as the sediment scouring efficiency (SSE). For the selected time intervals of $10 \mathrm{~min}$, the test was shut down and the removed sediment was measured and weighed from the settling basin. The time variation of SSE is as shown in Figure 6. During the experiment, it was observed that at the beginning of the experiment, the sediment scouring is very strong and is discharged in high concentration. As the time passes, this trend decreases and finally reaches an equilibrium. Different researchers have used different methods for estimating the equilibrium time of the scour hole. Day et al. [13] stated that the scour hole dimensions reached the equilibrium state when the variation of the scour depth did not exceed the median sediment size in $1 \mathrm{~h}$ duration of the experiments. In order to obtain the equilibrium time for the experiments, some long duration experiments ( $3 \mathrm{~h}$ ) were conducted for different jet diameters and velocities. In this study, the equilibrium time of the scour was selected as the time when the scour depth reached $90 \%$ of the long duration scour depth. The sediment scouring profiles (Figure 7) for jettip velocities between 3 and $9 \mathrm{~m} / \mathrm{s}$, are shown in relation to 
the tank base (given as a zero depth). The dotted line indicates the original level of the sediment bed in the tank $\left(\mathrm{H}_{\mathrm{s}}=30 \mathrm{~mm}\right)$. As shown in Figure 5, the MATLAB ${ }^{\mathrm{TM}}$ protocol used to detect the bed interface worked well to quantify the steady-state profiles, for the range of jet velocities tested. Generally, the

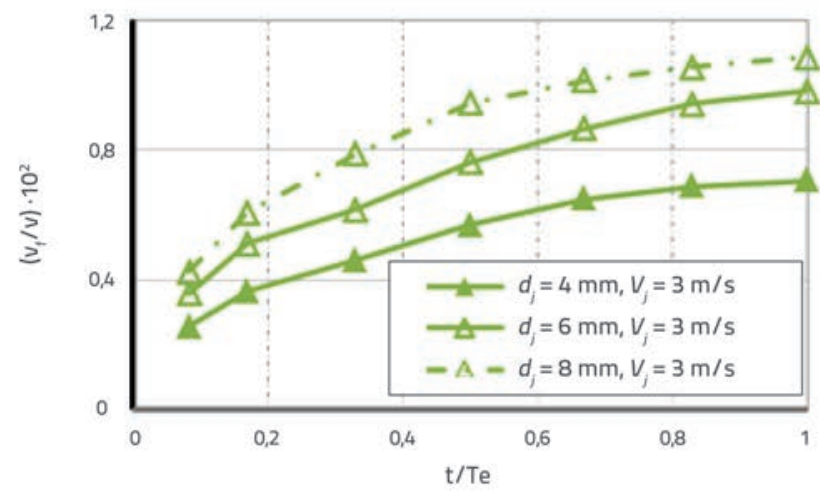

profiles suggest that the scour hole increase, in both depth and length, with jet velocity, is in line with expectations for cohesionless materials. Here, erosion occurs via the singleparticle momentum balance from the jet [14, 15]. As jet velocities increase, both the compressional pressure forces

Figure 6. Sediment scouring efficiency (SSE) as a function of time for jet experiments $\left(H_{\text {out }}=30 \mathrm{~cm}, Q_{\text {out }}=2,5 \mathrm{I} / \mathrm{s}\right.$ )
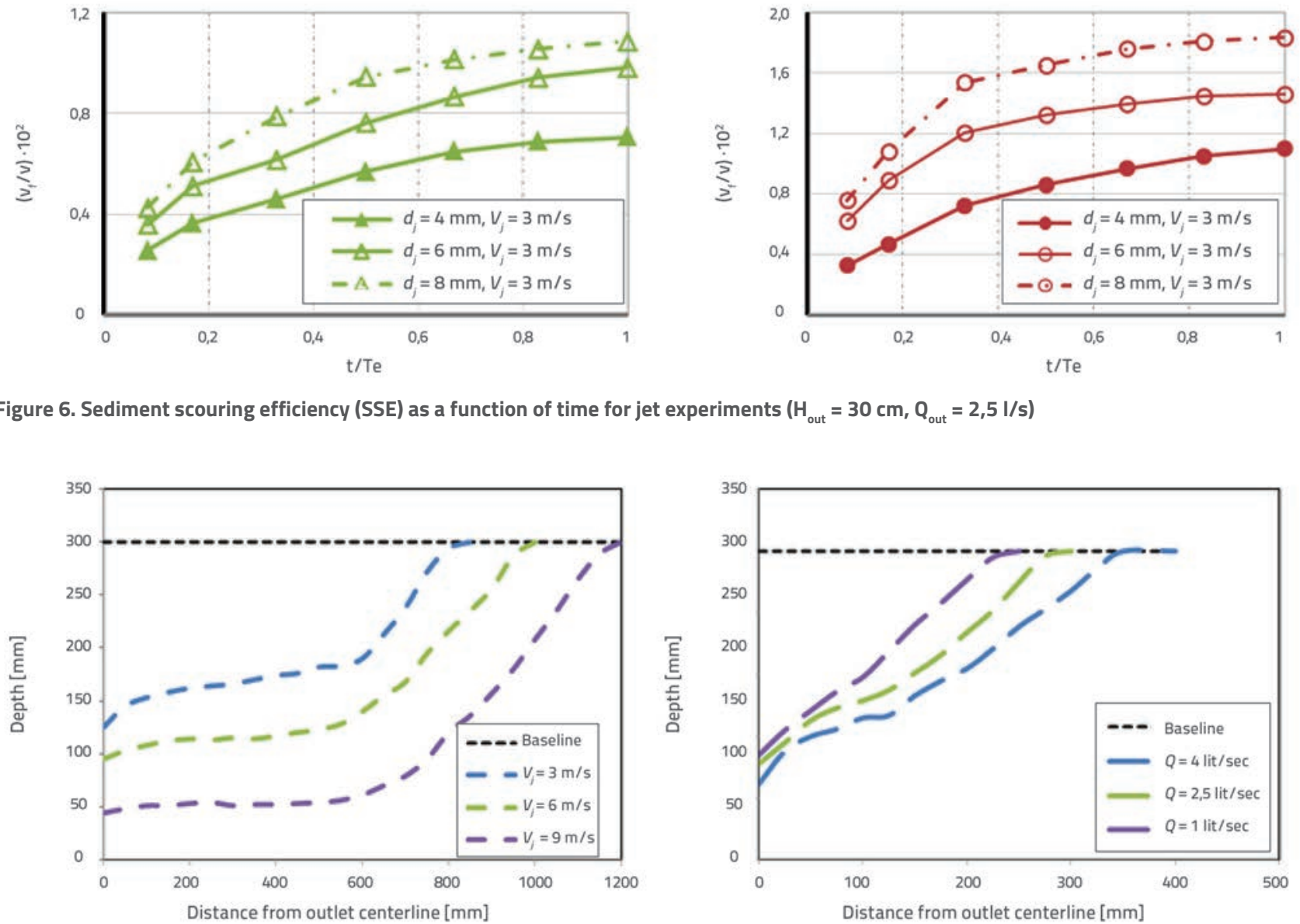

Figure 7. Comparison of longitudinal scour profiles: a) jet experiments; b) reference experiments (without jet)
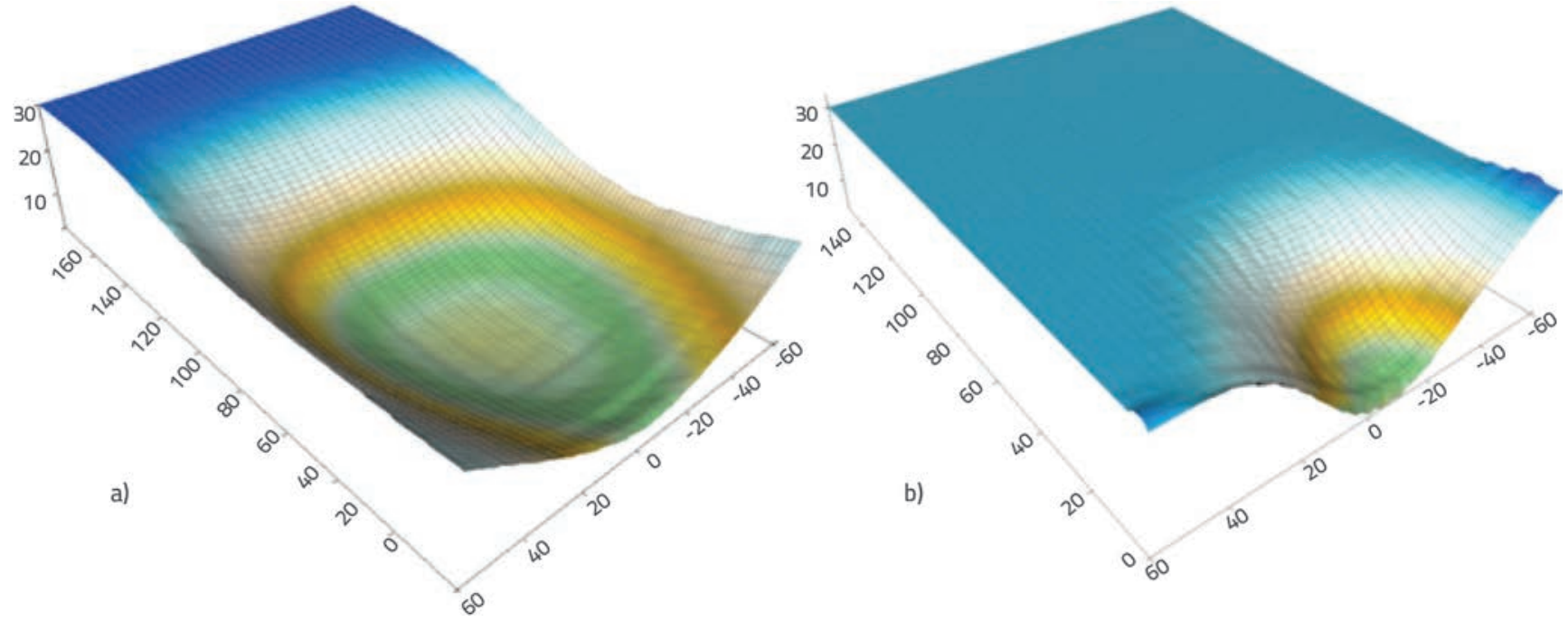

Figure 8. 3-Dimensional view of sediment scouring after experiment: a) jet experiment; b) reference experiment (without jet) 
and lateral shear forces increase. Together, this leads not only to an increase in the scour depth and size (as one might expect), but also to increased peak scour heights. The peak height of the scouring cone was around $120 \mathrm{~mm}$ for the jet velocity of $3 \mathrm{~m} / \mathrm{s}$, while it was about $250 \mathrm{~mm}$ for a jet velocity of $9 \mathrm{~m} / \mathrm{s}$. In the reference experiments (without jet), sediment scouring was confined to the outlet region only and, by getting further from that region, it lost its effect. The length of the scouring cone (the longitudinal distance formed in front of the bottom outlet from the frontal wall of the model to the final extension of the scouring cone) was about $350 \mathrm{~mm}$, and the maximum depth of the scour hole was about $190 \mathrm{~mm}$ for the experiments with maximum discharge. In jet experiments, the scouring dimension was larger and covered a larger region, so that the scouring length even reached $1200 \mathrm{~mm}$. A 3D view of the obtained profile of outlet surrounding scouring, by SURFER, after reference and jet experiments, is shown in Figure 8.

Investigation of the impact of bottom outlet level change shows that, at lower levels, the extension rate of scouring dimensions increases and more sediments are discharged (Figure 9). But it must be mentioned that over deposition of sediments results in the enhancement of deposited sediments strength, which could be a problem in discharging the sediments. In such cases, extra measures would need to be taken to facilitate sediment removal, which generates additional cost. It was also observed that when the level of sediments is equal to the bottom outlet level $\left(\mathrm{H}_{\mathrm{s}}=\mathrm{H}_{\text {out }}\right)$, the jets, in addition to increasing bed decay and carrying sediments forward, would suspend them and guide them to the outlet, therefore preventing their deposition. Depending on the jet velocity and nozzle diameter, SSE ranged from 0.7 to 2.3 at upper outlet levels $\left(H_{\text {out }}=30 \mathrm{~cm}\right.$ ), while SSE ranged from 0.9 to 3.1 at lower outlet levels $\left(H_{\text {out }}=15 \mathrm{~cm}\right)$. The effect of output discharge on the amount of sediment scouring is shown In Figure 10.a for jet experiments. The output discharge only has an effect on the regions near the outlet and by getting further, it loses its influence. Therefore, SSE decreases with an increase in output discharge. In very low discharges (lower than $1 \mathrm{~L} / \mathrm{s})$, the sediments accumulate at the gate of the outlet, and no sediment could be removed as the accumulated sediments

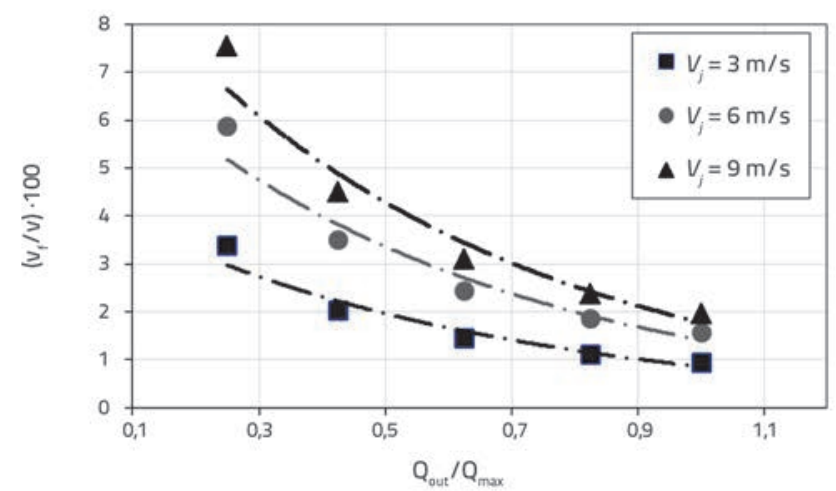

will actually close the gate. Therefore, for having an appropriate efficiency and performance, the outlet discharge should be selected in a special range so that it does not lead to the high loss of reservoir volume capacity or outlet blockage. As shown in Figure 10b, reduction of water height will result in an increase of the scouring cone volume. This means that in a fixed discharge, the lower the hydraulic sediment scouring performed, the larger the scour cone dimension. By decreasing reservoir height to maintain the discharge, the opening of the bottom outlet gate should be increased, which would lead to an increase of the region affected by sediment scouring, and more sediments would be removed. In the pressurized sediment scour, to gain better efficiency, the height of the reservoir water should be reduced as much as the conditions allow. SSE values are in the range of 0.1 to 0.3 , for the $1 \mathrm{~h}$ period of reference experiment. This is in complete agreement with previous studies by Moris and Fan [16] and Emamgholizadeh [17].

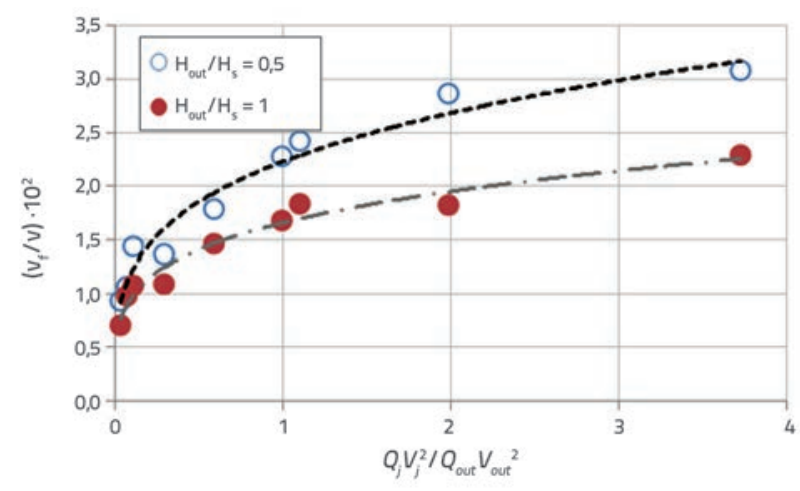

Figure 9. Effects of elevations of output on sediment scouring (horizontal axis represents ratio of the output power of jets, $Q_{j} V_{j}^{2}$ to the output power of the reservoir, $Q_{\text {out }} V_{\text {out }}{ }^{2}$ )

Because the sediments were assumed to erode in a cohesionless manner, their erosion was normalized as considered by Rajaratnam et al. [18]. This method relies on the calculation of what is known as the erosion parameter $E_{c^{\prime}}$ given in Equation 1. Essentially, it is an association of the Froude number for particles, where the jet tip velocity $\left(V_{j}\right)$ is normalized with

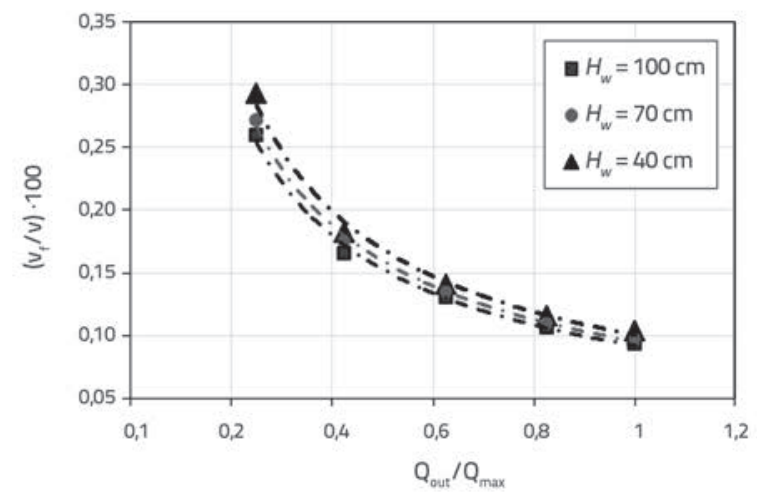

Figure 10. Sediment scouring efficiency (SSE) as a function of outlet discharge: for jet experiments; b) for reference experiments 
respect to the jet diameter (d) over the jet height (h) divided by a function of the particle fluid, incorporating the particle diameter (D) and the difference in density between the fluid and particle $\left(\Delta \rho / \rho_{\mathrm{f}}\right)$, as well as the gravitational constant $(\mathrm{g})$

$E_{c}=\frac{V_{j}\left(\frac{d_{j}}{h}\right)}{\sqrt{g D \frac{\Delta \rho}{\rho_{f}}}}$

It should be noted that the $\mathrm{D}_{90}$ and not the $\mathrm{D}_{50}$ particle diameters were used as the average in this analysis, as it has been shown to give better representation due to the larger size fractions dominating bed erodibility in cohesionless systems.

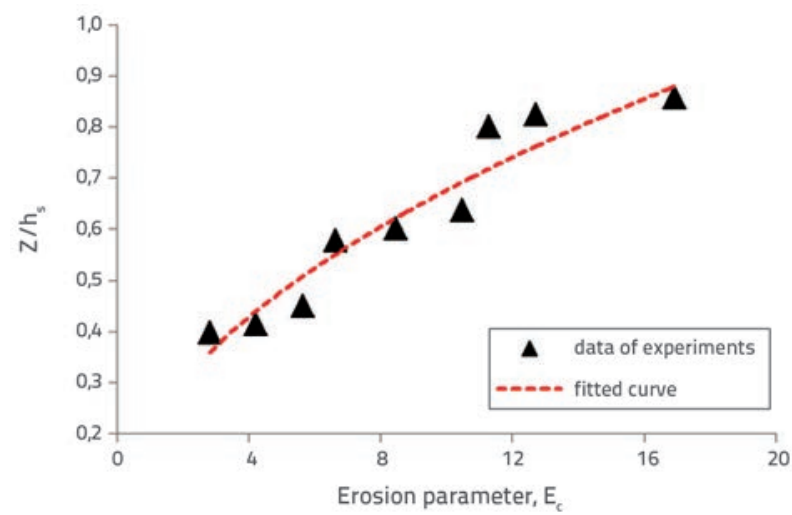

Figure 11. Relationship between maximum scour depth variation in sediment removal and erosion parameter $\left(E_{c}\right)$

Figure 11 shows the comparison between the maximum scours depth with respect to increasing $E_{c}$ numbers. Based on the curve fit of the data obtained from the experiments, it was found that the variation in the maximum scours depth generally grows with increased $E_{c}$. However, the changing trend of the experimental data remained broadly consistent with the fitting curve. With the experimental conditions constantly changing, the value of $E_{c}$ changed in the range of 3 to 17. At low velocities, there is surface attrition of particulates with the jet having low penetration, which increases initially with jet velocity. As the velocity increased over a certain threshold, the deflected jet flow resulted in the recirculation of particulates and fluid within the impingement zone. Correspondingly, this initially results in a reduction or stagnation of the measured static bed depths. At higher velocities, the particles are expelled into larger recirculation zones and the scour depth expands once more.

\section{Conclusion}

In this study, physical experiments were conducted on a rectangular reservoir to investigate the effect of the submerged jet on sediment removal in regions surrounding the outlet of the dam. In jet experiments, effective parameters such as jet velocity, nozzle diameter, output discharge, and outlet level, were considered. The results showed that SSE increases with an increase in jet velocity and nozzle diameter. Sensitivity analysis of the effective parameters showed that the variation of jet velocity has the highest sensitivity in sediment scouring. In high discharge, SSE was reduced and this reduction resulted in the loss of the reservoir saving volume. The jet method could be used at any level of sediment deposition $\left(\mathrm{H}_{\text {out }} / \mathrm{H}_{\mathrm{s}}=1\right)$, while in pressurized flushing, the sediments located at the lower level or at the level corresponding to the outlet level, would not be removed. For the tested discharge range, SSE varied between 0.9 and 3.1 for jet experiments, and it ranged between 0.1 and 0.3 for reference tests. This sediment scouring technique could be used for reservoirs with water source problems to avoid accumulation of sediments in dams, especially those in front of power intake.

\section{REFERENCES}

[1] Olsen, K.W., Bassoon, G.: 1D and 2D modeling of sedimentation and flushing in shallow reservoirs. Conference proceeding of Hydraulic of Dams and River Structures, Tehran, Iran, 2004.

[2] Dimitrov, B., Zhileska Panchovska, V.: Structure of price elements for construction works on water engineering systems, GRAĐEVINAR, 67 (2015) 4, pp. 363-368,

[3] Atkinson, E.: The feasibility of flushing sediment from the reservoir, Report OD 137. (Invited speaker) World Bank, Washington D.C., 1996.

[4] Rajaratnam, N., Mazurek, K.A.: Erosion of sand by circular impinging water jets with Small tailwater, J. Hydraulic Eng., 129 (2003) 3, pp. 225-229.

[5] Sequeiros, O.E., Niño, Y., Garcia, M.H.: Sedimentation management in combined sewer overflow storage reservoirs using water jets, Hyd. Eng. Series No. 76, UILU-ENG-2005-2001 Ven Te Chow Hydro systems Lab., University of Illinois at Urbana-Champaign, Urbana, USA, 2005.

[6] Mehraein, M., Ghodsian, M., Salehi Neyshaboury, S.A.A.: Local scour due to an upwards inclined circular wall jet, Proc. Ins Civil Engineers - Water Management, 164 (2011) 3, pp. 111-122.

[7] Fossett, H., Prosser, L.E.: The application of free jets to the mixing of fluids in bulk. Proceedings of I Mechanical Engineering, pp. 224232, 1949.

[8] Patwardhan, A.W., Gaikwad, S.G.: Mixing in tanks agitated by jets. Chemical Engineering Research and Design, 81 (2003) 2, pp. 211220.

[9] Zughbi, H.D., Rakib, M.A.: Mixing in a fluid jet agitated tank: effects of jet angle and elevation and number of jets. Chemical Engineering Science, 59 (2004) 4, pp. 829-842.

[10] Perona, J.J., Hylton, T.D., Youngblood, E.L., Cummins, R.L.: Jet mixing of liquids in long horizontal cylindrical tanks. Industrial and Engineering Chemistry Research, 37 (1998) 4, pp. 1478-1482. 
[11] Blevins, R.D.: Applied fluid dynamics handbook, Reprint edition with corrections, Krieger Publishing Company, Malabar, Florida, 1984.

[12] Jenzer Althaus, J., Cesare, G., Schleiss, A.: Sediment Evacuation from Reservoirs through Intakes by Jet-Induced Flow, J. Hydraul. Eng., 141 (2015) 2, Paper 04014078, doi: 10.1061/(ASCE) HY.1943-7900.0000970

[13] Day, R.A., Liriano., S., White, R.W.: Effect of tailwater depth and model scale on scour at culvert outlets, Proceedings of the Institution of Civil Engineers Water \& Maritime Engineering, 148 (2001) 3, pp. 189-198.

[14] Hogg, A.J., Huppert, H.E., Dade, W.B.: Erosion by planar turbulent wall jets. Journal of Fluid Mechanics, 338 (1997), pp. 317-340.
[15] Mazurek, K.A., Hossain, T.: Scour by jets in cohesionless and cohesive soils. Canadian Journal of Civil Engineering, 34 (2007), pp. 744-751.

[16] Morris, G.L., Fan, J.: Reservoir Sedimentation Handbook: Design and Management of Dams, Reservoirs, and Watersheds for Sustainable Use, McGraw-Hill, New York, 1998.

[17] Emamgholizadeh, S., Fathi-Moghdam, M.: Pressure Flushing of Cohesive Sediment in Large Dam Reservoirs, J. Hydrol. Eng., 19 (2014) 4, pp. 674-681.

[18] Aderibigbe, 0.O., Rajaratnam, N.: Erosion of loose beds by submerged circular impinging vertical turbulent jets. Journal of Hydraulic Research, 34 (1996), pp. 19-33. 